\title{
Particulate matters: student-led air quality research in the third-year environmental chemistry classroom and the field
}

\author{
Sherry Gao ${ }^{1} \cdot$ Robert W. Hilts ${ }^{2} \cdot$ Matthew S. Ross ${ }^{2} \cdot$ Sarah A. Styler ${ }^{1}$ \\ Published online: 25 April 2018 \\ (C) Springer-Verlag GmbH Germany, part of Springer Nature 2018
}

\section{Introduction}

\section{CHEM 305 and project-based learning}

Environmental Chemistry II (CHEM 305) is a single-semester undergraduate environmental chemistry course offered at the University of Alberta. The course covers a broad range of topics, including sorption and phase partitioning; hydrolysis reactions; diffusion; properties and behavior of particles, including sedimentation, coagulation, and light scattering; and the significance of particulate matter in the atmosphere. The student population is similarly diverse: in Winter 2017, for example, only nine of the 22 students taking the course were enrolled in the focused BSc Honors and BSc Specialization programs offered by the Department of Chemistry; in addition, of the students enrolled in general programs, three were pursing minors in chemistry and one was not pursuing a chemistry degree at all.

CHEM 305 is a laboratory-focused course in which lectures provide students with the theoretical background required to understand the experiments they will perform and build on those experiments by illustrating real-world applications of relevant concepts. CHEM 305 laboratories currently focus on student technical skill development, and are thus highly structured. Given the course's diverse enrolment, however, we saw value in exposing students - many of whom will not pursue careers in chemistry - to all steps of the scientific research process, from hypothesis development to communication of final results.

Sarah A. Styler

sstyler@ualberta.ca

1 Department of Chemistry, University of Alberta, Edmonton, AB T6G 2G2, Canada

2 Department of Physical Sciences, MacEwan University, Edmonton, AB T5J 4S2, Canada
In Winter 2017, we integrated a new project-based learning (PBL) component into CHEM 305. PBL is a pedagogical approach in which students actively participate in the investigation of real-world problems and in the process gain experience in asking questions, predicting results, designing and carrying out experiments, analyzing data, and communicating results to others [1]. In the undergraduate chemistry context, PBL often takes the form of student-designed research projects of varying scope and complexity [2-9]. PBL and other active learning approaches can sometimes be met with student resistance [10], and student feedback collected as part of some of the PBL initiativescited above indicated that students were often challenged - and in some cases frustrated — by the process, despite also finding it rewarding [3, 9]. However, student responses also highlighted a wide range of benefits of PBL, including increased confidence in the laboratory and with research in general $[2,4$, 5], improved experimental design skills [4], and development of critical thinking skills $[5,9]$. In addition, students reported that they enjoyed the freedom to plan their own experiments and take ownership over their own projects $[2,3,8]$.

Given that the CHEM 305 curriculum includes a number of topics related to particle behavior, our PBL initiative consisted of student-led air quality monitoring projects conducted with the AirBeam monitor, a portable, low-cost instrument for measurement of fine particulate matter in the atmosphere. In this project, students were asked to engage with the primary literature to discover areas of current interest in urban and indoor air quality, formulate a hypothesis testable using the AirBeam, design and conduct an air sampling campaign, and prepare both an oral presentation and a journal-style article summarizing the main findings of their campaign and discussing its broader implications.

\section{$\mathrm{PM}_{2.5}$ : sources, impacts, and monitoring}

$\mathrm{PM}_{2.5}$ - particulate matter (PM) with a diameter less than 2.5 micrometers - is released directly into the atmosphere by both natural sources, such as forest fires and volcanic eruptions, and anthropogenic sources, such as vehicles and industrial processes 
[9]. It also forms in the atmosphere via the oxidation of precursor emissions $[9,10] . \mathrm{PM}_{2.5}$ is not a homogeneous entity but rather is made up of a complex mixture of particles, the chemical composition of which changes with atmospheric residence time $[11,12]$.

As a result of its small size, $\mathrm{PM}_{2.5}$ can deposit farther into the human respiratory system than larger particles, and consequently has an increased negative impact on human health [13]. In 1993, Dockery et al. reported a strong correlation between $\mathrm{PM}_{2.5}$ levels and mortality rates in six United States cities [14]. This study, commonly referred to as the Six Cities study, played a major role in the subsequent United States Environmental Protection Agency (EPA) decision to establish new regulations specifically for $\mathrm{PM}_{2.5}$ [15].

Measurement of ambient $\mathrm{PM}_{2.5}$ concentrations is typically conducted at fixed air quality monitoring stations, which often also collect meteorological data and concentrations of other regulated pollutants (e.g., $\mathrm{NO}_{2}$ and $\mathrm{O}_{3}$ ). In the Edmonton area alone, Alberta Environment and Parks runs eight air quality monitoring stations [16]. In Canada, chemically speciated $\mathrm{PM}_{2.5}$ measurements are made as part of the National Air Pollution Surveillance (NAPS) program [17]. In the United States, these measurements are conducted through the $\mathrm{PM}_{2.5}$ Chemical Speciation Monitoring Network (CSN) and the Interagency Monitoring of Protected Visual Environments (IMPROVE) network [18].

Air quality monitoring networks are designed to provide insight into pollutant exposure at the population rather than individual level. In recent years, however, advances in sensor technology [19], coupled with measurements of strong spatial gradients in air quality [20,21], have spurred interest in personal pollutant exposure assessment $[22,23]$. In this context, growing numbers of manufacturers are producing compact, inexpensive, and portable $\mathrm{PM}_{2.5}$ monitors suitable for this purpose, including the Dylos, MetOne, Air Quality Egg, and AirBeam monitors [24]. All of these devices are significantly less expensive than conventional $\mathrm{PM}_{2.5}$ monitoring equipment, and are therefore also ideal tools for classroom exploration of air quality issues.

\section{Materials and methods}

\section{The AirBeam PM $_{2.5}$ monitor}

The AirBeam (http://www.takingspace.org/aircasting/ airbeam/) is a low-cost, portable instrument that uses a light scattering method to determine $\mathrm{PM}_{2.5}$ mass concentrations $\left(\mu \mathrm{g} \mathrm{m}^{-3}\right)$ in ambient air. Measurements are communicated once per s via Bluetooth to the AirCasting Android mobile app, which allows for real-time visualization of $\mathrm{PM}_{2.5}$ data. Collected data can also be uploaded to the AirCasting crowdsourced air quality map (http://www.aircasting.org/map) for others to view. The AirBeam sampler used in this study has recently been discontinued; a new version released in March 2018, AirBeam2, has additional functionality.
Several studies have shown that AirBeam measurements of ambient and laboratory $\mathrm{PM}_{2.5}$ are reasonably well-correlated $\left(\mathrm{R}^{2}=0.42-0.94\right)$ with those from co-located EPA-approved analytical instruments [24-26]. However, the AirBeam has been shown to exhibit a negative bias compared with $\mathrm{PM}_{2.5}$ levels reported by these reference instruments, especially at elevated $\mathrm{PM}_{2.5}$ concentrations, which restricts its use in a regulatory context $[25,26]$. Despite this limitation, it remains suitable as a teaching tool, especially since our students' research projects primarily involve measurement of changes in $\mathrm{PM}_{2.5}$ levels in response to emission events or changes in sampling location.

\section{Project structure and course integration}

In order to successfully complete the PBL component of CHEM 305, students were required to conduct literature searches, propose a research project, design and perform experiments, give an oral presentation, and complete a final written report. Although students worked in self-selected partners or groups of three, each student was required to submit an individually written research proposal and final report in the style of a journal article, the latter of which was due on the final day of the term.

As outlined in the class syllabus provided in the electronic supplementary material, although the project itself was conducted outside of the classroom, three class periods were reserved for project-related lectures. The first such lecture, reproduced in the electronic supplementary material, served to introduce students to $\mathrm{PM}_{2.5}$ and its significance, outline current research interests in the field, and motivate and inspire students to develop their own research projects. The second lecture, delivered by a science librarian, focused on strategies for engagement with the primary literature. The third lecture, delivered by a representative from the University of Alberta's Centre for Writers, focused on the development of science writing skills.

After the second in-class lecture, students were given 3 wk to independently engage with the primary literature, propose a suitable research question/hypothesis, and develop a detailed experimental plan. Throughout this period, students were encouraged to meet with the instructor to discuss their plans and receive feedback on their research proposals; many student groups took advantage of this opportunity. Student projects were conducted over a 1-mo period; during this time, students used an online booking system to sign out AirBeam monitors and accompanying Android tablets for 1-wk blocks.

The culmination of the project was the CHEM 305 Research Symposium, which took place over six class periods in March-April 2017. During the symposium, student groups delivered 15-min presentations that summarized the results of their research projects. The audience was encouraged to ask questions, which strengthened the presenters' 
ability to communicate scientific results in a conference setting.

\section{Project grading}

Templates and guideline documents were provided to students to aid them in writing their project proposals and final project reports. Student proposals and project reports were graded by the instructor according to the detailed grading schemes presented in these documents. Student presentations were peer graded according to five evaluation criteria: sufficient contextualization of the project; clear presentation of data; discussion of the "take-home" message of the project; oral presentation skills; and visual quality of the presentation

Table 1 Student research projects: activities and main findings

\begin{tabular}{|c|c|c|c|}
\hline \# & Project Title & Student Activities & Student Findings and Conclusions \\
\hline \multicolumn{4}{|c|}{ Experiments conducted in the field (i.e., using existing environments) } \\
\hline 1 & $\begin{array}{l}\text { Combustion particulate matter: assessing } \\
\text { potential health implications of candle } \\
\text { use in restaurants }\end{array}$ & $\begin{array}{l}\text { Evaluated potential influences on candle } \mathrm{PM}_{2.5} \\
\text { emission (igniting, flickering, and } \\
\text { extinguishing) }\end{array}$ & $\begin{array}{l}\text { - } \mathrm{PM}_{2.5} \text { did not increase significantly for } \\
\text { well-ventilated rooms } \\
\text { - Extinguishing of candles produced more } \\
\mathrm{PM}_{2.5} \text { than burning of candles }\end{array}$ \\
\hline 2 & $\begin{array}{l}\text { Distribution of } \mathrm{PM}_{2.5} \text { sources in a } \\
\text { university food court and } \\
\text { concentration change with time }\end{array}$ & $\begin{array}{l}\text { Measured } \mathrm{PM}_{2.5} \text { in front of individual food } \\
\text { vendors at various times of day }\end{array}$ & $\begin{array}{l}\text { - } \mathrm{PM}_{2.5} \text { was affected by both ventilation } \\
\text { efficiency and cooking style } \\
\text { - Customers can reduce } \mathrm{PM}_{2.5} \text { exposure by } \\
\text { standing farther away from kitchens and } \\
\text { avoiding rush hours }\end{array}$ \\
\hline 3 & $\begin{array}{l}\text { Indoor construction site and the influence } \\
\text { on ambient air quality }\end{array}$ & $\begin{array}{l}\text { Assessed the effect of construction activities on } \\
\mathrm{PM}_{2.5} \text { levels }\end{array}$ & $\begin{array}{l}\text { - } \mathrm{PM}_{2.5} \text { levels decreased with distance from } \\
\text { construction area } \\
\text { - Good ventilation and filtration masks are } \\
\text { essential for construction workers' health }\end{array}$ \\
\hline 4 & $\begin{array}{l}\mathrm{PM}_{2.5} \text { exposure in Edmonton's light rail } \\
\text { transit (LRT) system during winter } \\
\text { commuting time }\end{array}$ & $\begin{array}{l}\text { Measured } \mathrm{PM}_{2.5} \text { in LRT stations and on LRT } \\
\text { trains as a function of time of day }\end{array}$ & $\begin{array}{l}\text { - } \mathrm{PM}_{2.5} \text { was significantly higher during } \\
\text { busy commute times } \\
\text { - Opening the LRT door decreased } \mathrm{PM}_{2.5} \\
\text { temporarily }\end{array}$ \\
\hline 5 & $\begin{array}{l}\text { Associations between commuting } \\
\text { method and } \mathrm{PM}_{2.5} \text { emission/exposure } \\
\text { by transportation during the winter } \\
\text { season in Edmonton, Canada }\end{array}$ & $\begin{array}{l}\text { Measured } \mathrm{PM}_{2.5} \text { inside buses and private } \\
\text { vehicles as they travelled along a specific } \\
\text { route and compared to pedestrian exposure } \\
\text { on the same route }\end{array}$ & $\begin{array}{l}\text { - People commuting using any of these } \\
\text { three methods were exposed to similar } \\
\mathrm{PM}_{2.5} \text { levels }\end{array}$ \\
\hline 6 & $\begin{array}{l}\text { Measurement and evaluation of } \mathrm{PM}_{2.5} \\
\text { from secondhand smoke to verify } \\
\text { Edmonton smoking bylaws }\end{array}$ & $\begin{array}{l}\text { Investigated the influence of ventilation, } \\
\text { sampling distance, and number of smokers } \\
\text { on } \mathrm{PM}_{2.5} \text { levels }\end{array}$ & $\begin{array}{l}\text { - The Edmonton smoking bylaw was } \\
\text { effective in maintaining } \mathrm{PM}_{2.5} \text { levels } \\
\text { below air quality limits when }<4 \text { smokers } \\
\text { were present } \\
\text { - Smoking in poorly ventilated areas poses } \\
\text { substantial health risk }\end{array}$ \\
\hline \multicolumn{4}{|c|}{ Experiments conducted at home (i.e., using self-created, controlled sampling environments) } \\
\hline 7 & $\begin{array}{l}\text { Measurement of indoor } \mathrm{PM}_{2.5} \text { emission } \\
\text { from heating of five types of cooking } \\
\text { oils }\end{array}$ & $\begin{array}{l}\text { Assessed the influence of oil type, presence of } \\
\text { food, and cooking temperature on } \mathrm{PM}_{2.5} \\
\text { emission from cooking, and determined the } \\
\text { time required for } \mathrm{PM}_{2.5} \text { dissipation after } \\
\text { cooking }\end{array}$ & $\begin{array}{l}\text { - Different oils produced different levels of } \\
\mathrm{PM}_{2.5} \\
\text { - Higher cooking temperatures resulted in } \\
\text { higher } \mathrm{PM}_{2.5} \text { emission } \\
\text { - Ventilation accelerated } \mathrm{PM}_{2.5} \text { dissipation } \\
\text { after cooking }\end{array}$ \\
\hline 8 & $\begin{array}{l}\text { Correlation between indoor } \mathrm{PM}_{2.5} \text { and } \\
\text { essential oil }\end{array}$ & $\begin{array}{l}\text { Measured } \mathrm{PM}_{2.5} \text { emitted by reed diffusers } \\
\text { charged with } 6 \text { different scented essential oils }\end{array}$ & $\begin{array}{c}\text { - There was no correlation between the use } \\
\text { of essential oil and indoor } \mathrm{PM}_{2.5} \text { levels }\end{array}$ \\
\hline 9 & $\begin{array}{l}\text { The candle scandal: the effect of organic } \\
\text { and synthetic candles on air quality in } \\
\text { the home }\end{array}$ & $\begin{array}{l}\text { Tested the influence of organic and synthetic } \\
\text { candles on indoor } \mathrm{PM}_{2.5} \text { levels }\end{array}$ & $\begin{array}{l}\text { - } \mathrm{PM}_{2.5} \text { emissions from organic and } \\
\text { synthetic candles were similar } \\
\text { - } \mathrm{PM}_{2.5} \text { levels were highest at time of candle } \\
\text { extinguishing }\end{array}$ \\
\hline 10 & $\begin{array}{l}\text { Variations in } \mathrm{PM}_{2.5} \text { filtration by } \\
\text { disposable filtration masks }\end{array}$ & $\begin{array}{l}\text { Built an apparatus to monitor } \mathrm{PM}_{2.5} \text { levels from } \\
\text { candles before and after passage through } \\
\text { disposable dust filtration masks }\end{array}$ & $\begin{array}{l}\text { - The masks tested did not provide } \\
\text { protection against elevated } \mathrm{PM}_{2.5} \text { levels }\end{array}$ \\
\hline 11 & $\begin{array}{l}\text { Re-suspension of } \mathrm{PM}_{2.5} \text { during the use of } \\
\text { vacuum on carpets }\end{array}$ & $\begin{array}{l}\text { Measured } \mathrm{PM}_{2.5} \text { levels while walking on carpet } \\
\text { and while vacuuming }\end{array}$ & $\begin{array}{l}\text { - Vacuuming did not result in an increase in } \\
\mathrm{PM}_{2.5} \\
\text { - Walking on carpet caused an increase in } \\
\mathrm{PM}_{2.5}\end{array}$ \\
\hline
\end{tabular}


slides. Student participation during the presentations and the quality of students' peer-review comments were also graded, which encouraged students to engage in critical thinking and pose meaningful questions. All guideline and grading documents are provided in the electronic supplementary material.

\section{Results and discussion}

\section{Student research outcomes}

Although all students were provided with the same tool, the AirBeam air quality monitor, the research autonomy provided through PBL allowed students to be flexible with their experimental emphasis. As shown in Table 1, students used the AirBeam to answer research questions on topics ranging from the influence of candle burning on indoor air quality to the effectiveness of local smoking bylaws and in locations ranging from light rail transit platforms to construction sites. Since our primary focus here is not to evaluate the specific research outcomes of each individual project but rather to assess the pedagogical utility of the PBL process itself, we present in the following paragraphs several overarching insights collected from selected student projects.

Some student groups chose to focus on the measurement of $\mathrm{PM}_{2.5}$ concentrations in readily available field environments and the subsequent interpretation of the data collected. For example, one group investigated the effect of paraffin table candles on air quality in a restaurant where one group member worked (Project 1), and a second group measured $\mathrm{PM}_{2.5}$ levels in a busy university food court (Project 2). As shown in Fig. 1, students in the second group could see a measurable increase in $\mathrm{PM}_{2.5}$ concentrations as they passed an open-kitchen food vendor, which simultaneously highlights the spatiotemporal variability of $\mathrm{PM}_{2.5}$ levels and the utility of personal air quality measurements.

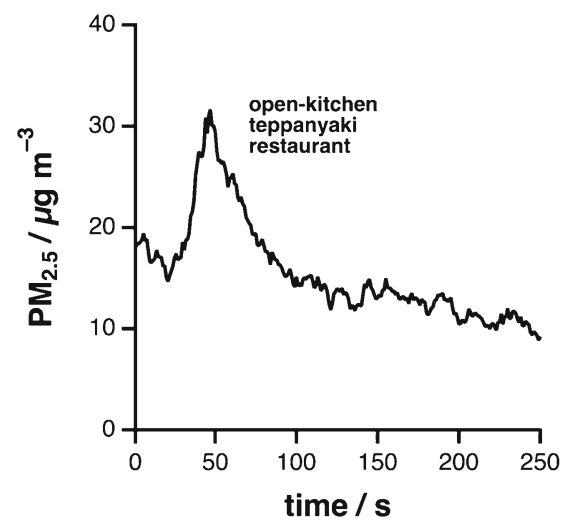

Fig. 1 Real-time AirBeam measurements of $\mathrm{PM}_{2.5}$ concentrations during a one-way walk through a segment of a university food court
Although the AirBeam is an excellent pedagogical tool for measuring ambient $\mathrm{PM}_{2.5}$ levels in different environments, some students chose to study changes in $\mathrm{PM}_{2.5}$ levels as a result of experiments performed under (relatively) controlled conditions, and thereby gain experience with the experimental design process. For example, one student group investigated correlations between cooking practices and indoor $\mathrm{PM}_{2.5}$ exposure (Project 7). In particular, these students measured $\mathrm{PM}_{2.5}$ concentrations as a function of cooking oil type, the presence/absence of food, cooking temperature, and the distance between the AirBeam and the cooking surface. As a result of their systematic approach to the project, these students were able to conclude that $\mathrm{PM}_{2.5}$ concentrations were positively correlated with cooking temperature and inversely correlated with the smoke point of the oils and the measurement distance. In another case (Project 10), students built a custom experimental apparatus to evaluate the effectiveness of two types of low-cost, single-use dust filtration masks in reducing $\mathrm{PM}_{2.5}$ exposure. As shown in Fig. 2, these students used one AirBeam to measure $\mathrm{PM}_{2.5}$ concentrations immediately next to a burning candle and another AirBeam to measure $\mathrm{PM}_{2.5}$ concentrations in an enclosure, the inlet of which was equipped with the dust filtration mask of interest. Air flow through the enclosure was controlled using an AirChek personal air sampling pump, which these students took the initiative to learn how to use. Surprisingly, students in this group observed elevated $\mathrm{PM}_{2.5}$ concentrations in the enclosure, which suggests either that the masks employed were not effective in filtering combustion-generated $\mathrm{PM}_{2.5}$ or that the enclosure inlet was not completely sealed.

A separate group of students (Project 8) hypothesized that essential oil diffusers would serve as an indoor source of particulate matter (i.e., secondary organic aerosol) via reaction of volatile organic fragrance compounds with atmospheric oxidants [27], and thus that the AirBeam would measure elevated $\mathrm{PM}_{2.5}$ levels when essential oils were used. In this context, these students planned to study the influence of essential oil type on $\mathrm{PM}_{2.5}$ formation. However, through analysis of data

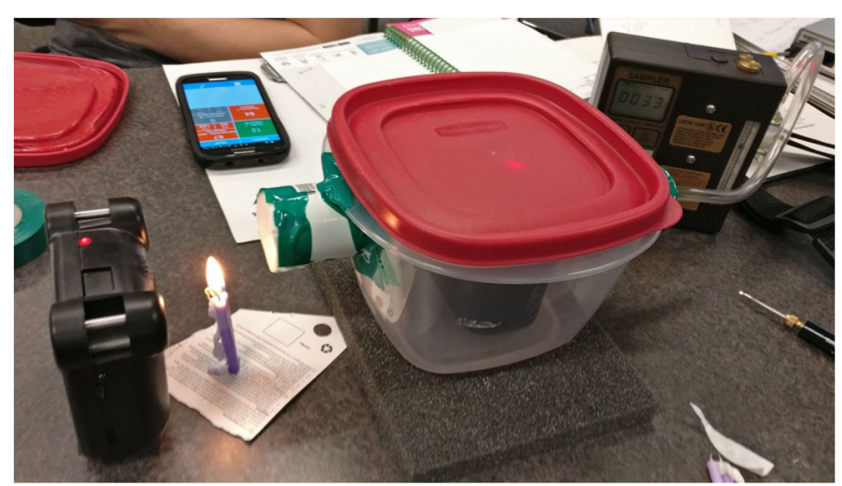

Fig. 2 Student-designed apparatus for investigation of the $\mathrm{PM}_{2.5}$ filtration efficiency of disposable dust filtration masks 
obtained during their experiments, students in this group found not only that there was no significant difference in $\mathrm{PM}_{2.5}$ production by the essential oils studied but also that the use of essential oils did not result in a measurable increase in $\mathrm{PM}_{2.5}$ levels. As a result of this experimental "failure", which is rare in a traditional classroom laboratory setting, these students learned to work with unexpected data in an ethical fashion, and came to realize that not all valid hypotheses are ultimately supported by experimental data.

Despite the range of research questions explored as part of this project, common results and themes emerged, and students thus had the opportunity to see how their individual research projects intersected with those of their peers. For example, two student groups explored the influence of candle combustion on indoor air quality - one group (Project 1) investigated the effect of paraffin oil candles on restaurant air quality, whereas another (Project 9) compared $\mathrm{PM}_{2.5}$ emission by organic and synthetic candles. In their reports, some students in these groups compared their results to previous work on $\mathrm{PM}_{2.5}$ emissions by candles [28], and others took the initiative to compare the maximum $\mathrm{PM}_{2.5}$ levels observed in their experiments to the Canadian Ambient Air Quality Standard for this pollutant class (Fig. 3). In both cases, students found that candles released a large amount of $\mathrm{PM}_{2.5}$ upon being extinguished. These results were subsequently applied by students in Group 10, who used extinguished candles as a source of $\mathrm{PM}_{2.5}$ with which to show that disposable dust filtration masks did not effectively reduce $\mathrm{PM}_{2.5}$ exposure. Results from this project, in turn, intersected with work by students in Project 3, who measured elevated $\mathrm{PM}_{2.5}$ levels in a construction zone on the same floor of the building where CHEM 305 classes were held. Together, these projects prompted discussion regarding the efficacy of typical personal protective equipment and highlighted the interdisciplinary nature of scientific research.

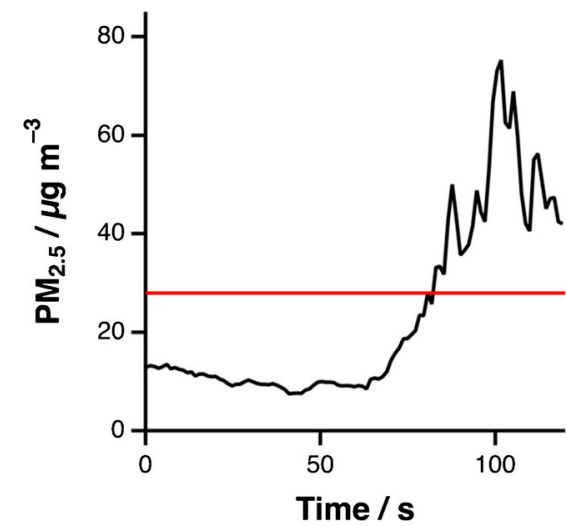

Fig. 3 Real-time AirBeam measurements of $\mathrm{PM}_{2.5}$ concentrations after extinguishing six candles in a restaurant setting. The horizontal red line represents the Canadian Ambient Air Quality Standards (CAAQS) red management level for $\mathrm{PM}_{2.5}\left(24 \mathrm{~h}\right.$ average; $28 \mu \mathrm{g} \mathrm{m}^{-3}$ )

\section{Summary of pedagogical outcomes}

Throughout the AirBeam project, CHEM 305 students were encouraged to chart their own paths, and thus discover both the challenges of independent research and the excitement that comes with obtaining results that are truly new. In the process, students gained experience with the entirety of the scientific research process, including literature engagement and hypothesis development, experimental design, selection and performance of appropriate control experiments, extraction of information (i.e., meaning) from complex data sets, and presentation of an overarching scientific narrative in both oral and written form. Perhaps most importantly, the breadth of topics explored during the AirBeam project highlights the project's success in encouraging students not only to find creative solutions to experimental challenges but also to ask creative questions.

\section{Broader applicability}

Given our demonstrated success in incorporating a PBL component into CHEM 305, we were interested in learning whether the AirBeam project could translate to other educational contexts. MacEwan University, also located in Edmonton, offers a second-year field-based physical sciences course (PHSC 200), which focuses on field skills development in environmental chemistry, earth science, and physics. The field component of this course is carried out in Edmonton and on the Big Island of Hawaii, and has traditionally included analysis of soil, water, and atmospheric gases. In Summer 2017, the course was modified to include the use of AirBeams to collect $\mathrm{PM}_{2.5}$ measurements at field sites in Edmonton (n $=3$ ) and Hawaii $(\mathrm{n}=10)$. All field exercise materials are presented in the electronic supplementary material.

Due to the more introductory nature and the shorter timeline (6 wk) of PHSC 200 compared with CHEM 305, a more traditional laboratory approach was taken, in which students were responsible for collecting data and answering instructor-developed questions that focused on comparing $\mathrm{PM}_{2.5}$ concentrations between sites and providing rationalizations for observed differences. For example, since the Hawaiian campaign included measurements at both sea-level and mountaintop sites, students were asked to explore the influence of elevation on $\mathrm{PM}_{2.5}$ concentrations. As expected, students observed low $\mathrm{PM}_{2.5}$ levels at most mountaintop sites (e.g., the Mauna Loa Observatory), which is consistent with the location of these sites in the free troposphere [9, 29].

Although most of the research questions generated by CHEM 305 students focused on anthropogenic influences on $\mathrm{PM}_{2.5}$ concentrations, PHSC 200 students made measurements in more remote areas, which enabled them to 
investigate natural sources of $\mathrm{PM}_{2.5}$. For example, students found elevated $\mathrm{PM}_{2.5}$ concentrations on Waipi'o Beach compared with the other remote sites studied, which highlights the importance of marine aerosol generation [30]. PHSC 200 students were also tasked with measuring $\mathrm{CO}, \mathrm{O}_{2}, \mathrm{SO}_{2}$, and $\mathrm{H}_{2} \mathrm{~S}$ concentrations at each of the sampling sites using a commercial gas analyzer (Altair 5X, MSA), and in some cases, students were able to use these measurements to provide additional insights into observed $\mathrm{PM}_{2.5}$ concentrations. For example, students found that concentrations of $\mathrm{SO}_{2}$ and $\mathrm{PM}_{2.5}$ were both elevated at Sulphur Banks (Ha'akulamanu), Hawaii Volcanoes National Park, which may have reflected the formation of sulfate aerosol from precursor gases [9]. In summary, the use of AirBeams in PHSC 200 demonstrates both the utility of these monitors in a non-PBL setting and the broader applicability of AirBeams as a tool to investigate and teach natural phenomena in a field setting.

Acknowledgments The authors thank the City of Edmonton, the Office of Sustainability at the University of Alberta, and the Department of Physical Sciences at MacEwan University for providing the AirBeam air monitors employed in this study. They thank the Undergraduate Research Initiative at the University of Alberta for summer funding for Sherry Gao. They thank Chris Rutter for assistance with construction site sampling and Dr. Bernadette Quémerais for use of her AirChek sampling pump. They thank the students in CHEM 305 (University of Alberta), CHEM 270 (MacEwan University), and PHSC 200 (MacEwan University) for their creativity and enthusiasm, without which this project would not have been possible.

\section{References}

1. Blumenfeld PC, Soloway E, Marx RW, Krajcik JS, Guzdial M, Palincsar A. Motivating project-based learning: sustaining the doing, supporting the learning. Educ Psychol. 1991;26:369-98. https://doi.org/10.1080/00461520.1991.9653139.

2. Iimoto DS, Frederick KA. Incorporating student-designed research projects in the chemistry curriculum. J Chem Educ. 2011;88:106973. https://doi.org/10.1021/ed1011103.

3. Robinson JK. Project-based learning: improving student engagement and performance in the laboratory. Anal Bioanal Chem. 2013;405:7-13. https://doi.org/10.1007/s00216-012-6473-x.

4. Graham KJ, Jones TN, Schaller CP, McIntee EJ. Implementing a student-designed green chemistry laboratory project in organic chemistry. J Chem Educ. 2014;91:1895-900. https://doi.org/10. 1021/ed5000394.

5. Hartings MR, Fox DM, Miller AE, Muratore KE. A hybrid integrated laboratory and inquiry-based research experience: replacing traditional laboratory instruction with a sustainable student-led research project. J Chem Educ. 2015;92:1016-23. https://doi.org/10. 1021/ed500793q.

6. Davis EJ, Pauls S, Dick J. Project-based learning in undergraduate environmental chemistry laboratory: using EPA methods to guide student method development for pesticide quantitation. J Chem Educ. 2017;94:451-7. https://doi.org/10.1021/acs.jchemed. $6 \mathrm{~b} 00352$.

7. Adami G. A new project-based lab for undergraduate environmental and analytical chemistry. J Chem Educ. 2006;83:253. https://doi. org/10.1021/ed083p253.
8. Bullen HA. Student-driven independent research projects: developing a framework for success in analytical chemistry. Anal Bioanal Chem. 2012;404:927-930. https://doi.org/10.1007/s00216-012-6153-x.

9. Arnold RJ. The water project: A multi-week laboratory project for undergraduate analytical chemistry. J Chem Educ. 2003;80:58. https://doi.org/10.1021/ed080p58.

10. Seidel SB, Tanner KD. "What if students revolt?"-considering student resistance: origins, options, and opportunities for investigation. CBE Life Sci Educ. 2013;12:586-95. https://doi.org/10.1187/ cbe-13-09-0190.

11. Rudich Y, Donahue NM, Mentel TF. Aging of organic aerosol: bridging the gap between laboratory and field studies. Annu Rev Phys Chem. 2007;58:321-52.

12. Fuzzi S, Baltensperger U, Carslaw K, Decesari S, Denier van der Gon H, Facchini MC, et al. Particulate matter, air quality, and climate: lessons learned and future needs. Atmos Chem Phys. 2015;15:8217-99.

13. Shiraiwa M, Ueda K, Pozzer A, Lammel G, Kampf CJ, Fushimi A, et al. Aerosol health effects from molecular to global scales. Environ Sci Technol. 2017;51:13545-67.

14. Dockery DW, Pope CA, Xu X, Spengler JD, Ware JH, Fay ME, et al. An association between air pollution and mortality in six U.S. cities. N Engl J Med. 1993;329:1753-9.

15. Dockery DW. Health effects of particulate air pollution. Ann Epidemiol. 2009;19:257-63.

16. Alberta Environment and Parks airdata warehouse. Available at: http://airdata.alberta.ca/aepContent/Reports/ StationInformationMain.aspx. Accessed 24 Dec 2017

17. Dabek-Zlotorzynska E, Dann TF, Kalyani Martinelango P, Celo V, Brook JR, Mathieu D, et al. Canadian National Air Pollution Surveillance (NAPS) $\mathrm{PM}_{2.5}$ speciation program: methodology and $\mathrm{PM}_{2.5}$ chemical composition for the years 2003-2008. Atmos Environ. 2011;45:673-86.

18. Solomon PA, Crumpler D, Flanagan JB, Jayanty RKM, Rickman EE, McDade CE. U.S. national $\mathrm{PM}_{2.5}$ chemical speciation monitoring networks - CSN and IMPROVE: description of networks. J Air Waste Manage Assoc. 2014;64:1410-38.

19. Snyder EG, Watkins TH, Solomon PA, Thoma ED, Williams RW, Hagler GSW, et al. The changing paradigm of air pollution monitoring. Environ Sci Technol. 2013;47:11369-77.

20. Olson DA, Hammond DM, Seila RL, Burke JM, Norris GA. Spatial gradients and source apportionment of volatile organic compounds near roadways. Atmos Environ. 2009;43:5647-53.

21. Karner AA, Eisinger DS, Niemeier DA. Near-roadway air quality: synthesizing the findings from real-world data. Environ Sci Technol. 2010;44:5334-44.

22. Steinle S, Reis S, Sabel CE. Quantifying human exposure to air pollution - moving from static monitoring to spatio-temporally resolved personal exposure assessment. Sci Total Environ. 2013;443:184-93.

23. Steinle S, Reis S, Sabel CE, Semple S, Twigg MM, Braban CF, et al. Personal exposure monitoring of $\mathrm{PM}_{2.5}$ in indoor and outdoor microenvironments. Sci Total Environ. 2015;508:383-94.

24. Jiao W, Hagler G, Williams R, Sharpe R, Brown R, Garver D, et al. Community Air Sensor Network (CAIRSENSE) project: evaluation of low-cost sensor performance in a suburban environment in the southeastern United States. Atmos Meas Tech. 2016;9:5281-92.

25. Sousan S, Koehler K, Hallett L, Peters TM. Evaluation of consumer monitors to measure particulate matter. J Aerosol Sci. 2017;107: 123-33.

26. Mukherjee A, Stanton L, Graham AR, Roberts PT. Assessing the utility of low-cost particulate matter sensors over a 12-week period in the Cuyama Valley of California. Sensors. 2017;17:1805.

27. Huang H-L, Sheu S-C, Wu Y-Y, Hsu D-J. Comparison of Chinese herbal oils and lemon oil for formation of secondary organic aerosol. Aerosol Air Qual Res. 2011;11:854-9. 
28. Petry T, Vitale D, Joachim FJ, Smith B, Cruse L, Mascarenhas R, et al. Human health risk evaluation of selected VOC, SVOC, and particulate emissions from scented candles. Regul Toxicol Pharmacol. 2014;69:55-70.

29. Bodhaine BA. Aerosol measurements at four background sites. J Geophys Res Oceans. 1983;88:10753-68.

30. Quinn PK, Collins DB, Grassian VH, Prather KA, Bates TS. Chemistry and related properties of freshly emitted sea spray aerosol. Chem Rev. 2015;115:4383-99.

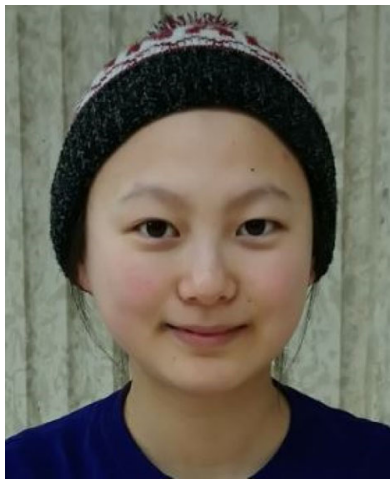

Sherry Gao is a third-year Engineering Physics undergraduate student at the University of Alberta, and has been working in the Styler Research Group since January 2016. She has a strong interest in sustainable power and energy systems, as well as environmental sciences.

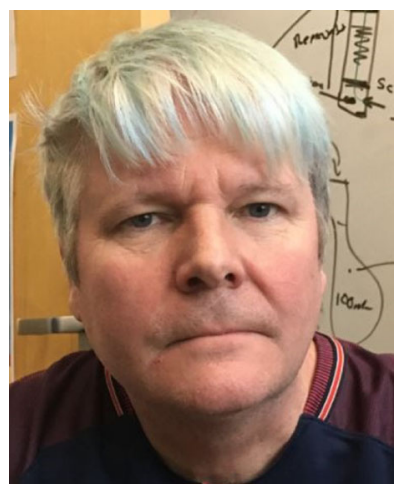

Robert Hilts is a chemistry faculty member at MacEwan University in Edmonton, Alberta. His research involves the study of organic compounds in carbonaceous chondrite meteorites. $\mathrm{He}$ began working at MacEwan University in 1996.

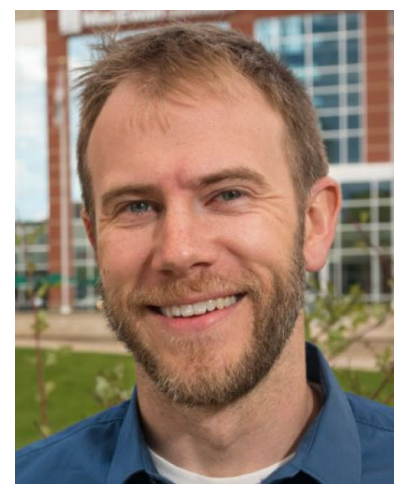

Matthew Ross is Assistant Professor in the Department of Physical Sciences at MacEwan University. He received his Bachelor of Science degree in biology from Arizona State University and a $\mathrm{PhD}$ in environmental and analytical chemistry from the University of Alberta. His multidisciplinary research encompasses areas such as environmental chemistry, analytical chemistry, and toxicology, with a focus on understanding the thropogenic pollutants in the environment. sources, transport, and fate of an-

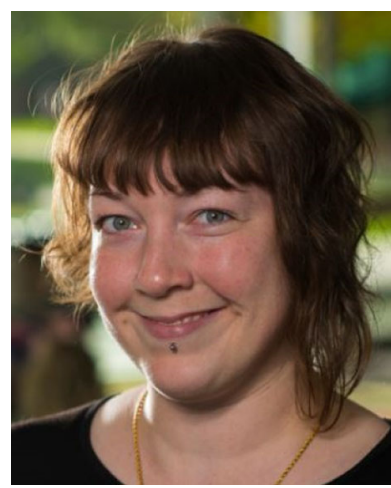

Sarah A. Styler obtained her $\mathrm{BSc}, \mathrm{MSc}$, and $\mathrm{PhD}$ degrees from the University of Toronto and conducted postdoctoral research at the Leibniz Institute for Tropospheric Research in Leipzig, Germany. In 2015, she joined the University of Alberta as Assistant Professor of Environmental Chemistry. Her group's research focuses on sunlight-induced chemistry in atmospheric particulate matter, especially in polluted and dustinfluenced urban environments, and the implications of this chemistry for air quality and health. 